\title{
The Usage of Green Gamification for Public Interest Function of Public Relations
}

\author{
Akbulut D. 1 \\ Yıldırım G. ${ }^{2}$ \\ ${ }^{1}$ Deniz Akbulut, İstanbul Aydın University, (Turkey) \\ e-mail: denizakbulut@aydin.edu.tr \\ ${ }^{2}$ Gonca Yıldırım, İstanbul Aydın University, (Turkey) \\ e-mail: goncayildirim@aydin.edu.tr
}

\begin{abstract}
In recent years, rapidly developing communication technologies change the way of life, habits of the people, and also the structures, business processes and policies of the institutions. Public relations, which is considered as a management function in institutions, is constantly developing and changing its tools and methods accordingly. Public relations, which establishes a bridge of communication between the institution and its target audiences, also tries to fulfill the obligations of institutions to provide public interest. Public relations, which tries to integrate the opportunities and tools of the changing digital world into communication activities, has to renew its projects for public benefit within the scope of this integration in terms of form and tool. Green gamification is a field used in the public interest in the world, mobilizing target groups in social sense and creating social sensitivity. Throughout the history, although the purpose of the games remained similar, their forms and tools have changed. Today, games have become one of the major tools in the digital world. The games and gamification studies offered by the digital world for public relations appear as an important tool for ensuring the continuity, interaction and diversity of the relationship established while entertaining the target audiences. Today, institutions have to work with multiple channels in order to reach the individuals who are constantly changing and transforming their wishes, habits and expectations. Within the scope of 360 -degree communication, public relations must integrate each work and each communication tool. In this regard, with the aim of creating attitudes and behavior change in the individuals within the frame of public interest, many examples from the world are encountered when the green gamification activities used in the digital world by public relations are examined. However, it is seen that the institutions in Turkey haven't developed themselves sufficiently in this respect. In this study, it is aimed to present a proposal for a model for Turkey by examining the green gamification studies which have started to spread around the world and found its area of execution in the frame of public interest.
\end{abstract}

Keywords: Public Relations, Public Interest, Green Gamification, Digital Public Relations.

\section{Introduction}

Public relations profession has obtained new functions through its evolutionary process over the years. Public relations is one of the primary actors that will provide the basis of reconciliation, partnership and cooperation between digitalizing, multicultural and postmodern world's transforming organizations and their target audiences. While organizations expect responsibilities from public relations such as reputation, image management, crisis communication, media relations and brand communication, target audiences also have expectations from the organizations. Target audiences and social stakeholders also expect to be informed, to be participated in decision-making processes of the brand, and want their wishes and demands to be heard. Public relations, main responsibilities of which are to look out for the public interest and strengthen public trust, have to fulfill these duties and responsibilities in different ways and dimensions in the digital world due to changing technology. One 
of them is gamification, which has started to lift its effectiveness in recent years. With its dynamics, mechanics and reward systems, gamification provides suitable environments for the socialization and social integration of the digitalized generations. Now that gamification, with its tactics and methods, has newly entered the studies of the organizations' marketing, human resources and public relations departments, it is attention-grabbing that, for instance, very few studies have been carried out in the field of public relations. Having been effective in warning and activating target groups in the presence of the changing and increasing problems of the world in recent years, green gamification is a current issue. Especially, linking green gamification and public relations and creating a model intended for the application, reveal the main purpose and importance of this study. It is thought that social responsibility-based green gamification applications will be used more intensively in public relations within the frame of sustainability projects.

\section{Literature}

\section{Public Interest Function of Public Relations}

Every organization has its main foundational purposes. Foremost among them are yielding and earning profits. After that, in line with their vision and mission, and pursuant to their sectors; organizations pursue to maintain their institutional entity with a range of business purposes such as growth, increasing market share, establishing new partnerships, extending to foreign markets, buying new businesses, entering new sectors, increasing the number of distributors, offering new products and brands to the market. In line with these goals, Bilgin (2010: 41) indicates the purposes of public relations in terms of organization as encouraging private entrepreneurship, protecting the business, empowering financially, earning reputation, developing relations, and also providing brand awareness, brand preference etc. Bilgin states that the social objectives of public relations are to enlighten the public, to ease the relations between public and administration, to provide cooperation with the public, to listen to the demands, complaints and requests of the public.

If organizations could keep their reality protecting public interest and are righteous in the activity that they are conducting, they can convince their target audience as well as easily refute the opposing campaigns that come from the rival organizations. The duty of a public relations specialist is not to do a campaign by any means, but to do what is right (Bilgin, 2010:201).

Interaction and communication works offered by public relations within the frame of public interest are also corporate social responsibility projects. Social responsibility activities are also considered as the projects that the organizations turn their faces to get rid of their target audiences' negative point of view as the harm they cause to the environment and nature increases and to meet the expectations of the target audiences expecting social awareness. According to Milton Friedman (1962), the only social responsibility of businesses is to increase profit. Nevertheless, organizations are expected to do more than just profit-making activities and have social awareness in today's competitive environment where the target audience becomes more selective. Today, businesses have to have the responsibility not only to their shareholders but also to society and all stakeholders. This necessitates more social awareness and related studies. As changing expectations of society play an important role in gaining new identity in terms of the organizations, public relations have the responsibility of responding to these social expectations (Göksel, 2013: 134; Maden, 2012: 172; L’Etang ve Pieczka, 2002: 160; Peltekoğlu, 2007: 187).

Sharpe, who says one of the ideal roles of public relations is mediation between the organization and the society, states that the purpose of public relations is harmonizing the social environment and the organization through constantly communicating to achieve mutual reliability, public trust, fair behavior, mutual understanding and respect. (Sharpe, 1990:23, as cited in L'etang and Pieczka, 2002:173)

One of the main goals of all these projects and activities on behalf of public interest and social responsibility is to raise awareness in the society, to evoke them, to create positive attitude and behavioral change, to establish an environment that is based on cooperation between the organization and the target audience in accordance with common interests. 
Remarking that the value of public relations frequently discussed within the scope of social value, Ehling (2005: 644) states that varied theoreticians tend to attribute the social role of public relations to corporate social responsibility in particular, and to the public interest in general.

Although there are lots of discussions and conceptual confusions over public interest/public benefit, in reality, this concept continues to be involved in public policy and regulation process. Public interest/public benefit appears as a concept used in a wide range of fields and disciplines that mostly cross with public relations over the last decades. Public interest, including the media, became the heart of many fields such as laws, politics, politics and regulation, anthropology, accounting/finance, psychology, economics, healthcare.

According to the modern definition that Public Relations Society of America (PRSA) defined in 2012, public relations is a strategic communication process that establishes mutually beneficial relations between organizations and their community. According to the definition of Canadian Public Relations Society (CPRS), public relations is the strategic communication management used for the mutual usage of relations between an organization and various communities, achieving its organizational goals and serving the public interest. It is seen that, both definitions emphasize the mutual benefit function between the establishment and target audiences of public relations.

According to Bivins (1993: 126), public relations have no choice but to define public interest in a way society accepts. Otherwise, it will mean deceiving the people. Bivins suggests implementers act for the benefit of individual clients, to make public relations services accessible to all those in need, and to serve the public interest.

Stating that the aspect of prioritizing public interest should be at the center of ethical practices, Messina (2007) points out that acting for public interest has become one of the most explicit functions in the sector. Mechling (1975) indicates that public relations has a certain capacity to work on public interest and also has the ability to achieve this.

The concepts, which prepare a necessary foundation for the realization of public relations projects in accordance with public interest, are concepts such as participation, responsibility, transparency, reconciliation and sustainability. In addition to these concepts, public engagement also forms the basis in this process. Yıldırım and Karafes (2011: 19) define public engagement as the concept which brings social synergy in the long term, as organizations and the public mutually taking on an obligation, working and acting together from the period of building trust to making it consistent.

Considering the scope of definitions, functions, duties and responsibilities of public relations, it is observed that there has been an increase in expectations and projects in line with public interest over the years. Especially with the improvement of technology, there is an increase in the number of consumer and citizen-oriented services and product designs. Today's internet generation comprises of individuals who love and prefer interaction, sharing, participation, cooperation, following, information transfer. These individuals have similar expectations not only in their personal lives, but also in social relations and economic and political processes. This condition leads public relations -as many other structures- to digital so that it can be closer to the target audience. The structure that is called as digital public relations (Digital PR) has gained a new dimension especially with the existence of social media environments.

\section{Digital Public Relations and Gamification}

Public relations having renewed itself as digital public relations in a world of digital media and information technologies, it appears in that world where people spending a long time in different roles and ways.

Digital-oriented integrated communication projects, such as social media management, social network labeling, dictionaries, blogs, forums, news sites, e-bulletins, e-mail marketing, search engine marketing (SEM), search engine optimization (SEO), corporate web design, news/ announcements/ interviews/publicity bulletins published in digital newspapers and magazines, online reputation management, online crisis management, content marketing on social media, press rooms, 
intranet/extranet applications, growth marketing etc., could be counted as the elements of digital public relations (Sözer, 2018; Kaygısız, 2016; Tezsezen, 2017).

Digital public relations have great importance with regards to organizations communicating the products and services to their potential buyers. Ensuring participation through platforms such as Ekşi Sözlük, personal blogs, şikayetvar, Trivago, Swarm, influencing consumer attitudes and thoughts through scoring, minimizing negative contents and conducting reputation management, reveal the importance of digital public relations. Besides, public relations have to be more active in managing today's crisis and conducting on social media and digital arena (Kaygısız, 2016). Making one-to-one communication with the target audience, showing active participation on social media in terms of brand image and continuity, and sharing regularly are important for digital public relations (Tezsezen, 2017).

Another digital means that provides one-to-one communication, interaction and feedback with the target audience is digital gamification. Game and playing game have been one of the keystones of our lives since the existence of humanity. One discovers sharing, learning, thinking, questioning, participation, and fun via games. Transferred from stones, bones, street to the digital, game has become one of the main activities of today's internet generation. Johan Huizinga (2018) underlines that the only thing as old as the history of mankind is the game.

Simon Sinek states that people satisfy their need for socialization-which is one of the main needs of them- through social media or games; even when at a meeting or at work time, they check on their e-mail, Whatsapp or social media accounts, and that there is a generation that gets what they want immediately, sees themselves at the heart of all processes and cannot focus on any subject fully. Sinek emphasizes the need for more innovative approaches such as feedback, target, intrinsic reward, appreciation, achievement and stories (cited by Yılmaz, 2018: 22-23).

Gamification is that using the way of thinking in the game and game rules for the purpose of attracting user's attention and solving problems (Zichermann ve Cunningham, 2011). Gamification gives an opportunity to build game-based communication with the target audience by benefiting from the digital and traditional game methods (Akbulut, 2018: 98). Gamification is an approach that solves the motivational problems of real-life with game design techniques, targeting behavioral change in long-term on participants. Gamification is not about playing a game; it is about applying game design techniques into non-game fields. Gamification, which aims to the "feelings of playing game" rather than just playing game, has three parameters such as a motivational problem, a game technique that one tries to solve, and directing one to behavioral change (YIImaz, 2018:28-29).

Gamification is the process which including something (a website, an organization application, an online community) that already exists and inserting the game mechanics in it to motivate participation and commitment. Gamification, using data-driven techniques, applies them to non-game experiences to motivate actions that add value to the work of individuals.

According to McGonigal (2011), four main features defining games are goals, rules, feedback system and voluntary participation. While the goals define the reasons why the players are there, what they want to reach; the rules show the players how to achieve these goals, what to do and what not to do. The rules force the players' creativity and strategic thinking. While the feedback system shows players how close they are to their goals, what they need; voluntary participation means the independence of the players and shows that all the players accept the goals, the rules and the conditions of feedback knowingly and willfully.

Werbach and Hunter presented a hierarchical model of dynamics, mechanisms, and components for gamification. According to this model, while dynamics create the big picture of the gamification system; mechanisms are the fundamental process that improves movement and enables player participation. Components are spesific samples of mechanics and dynamics. While Dynamics that form the construct of the game consist of the sub-factors that are constraints, emotions, narrative, progression, relationship; Mechanics consist of the factors such as challenges, chance, competition cooperation, feedback, rewards, transactions, resource acquisition, turns, win states. Gamification Components consist of the factors such as achievements, avatars, badges, leaderboards, levels, 
virtual goods, etc. Sub-factors of dynamics, mechanisms and components consist of the following (Figure 1) (Werbach and Hunter, 2015):

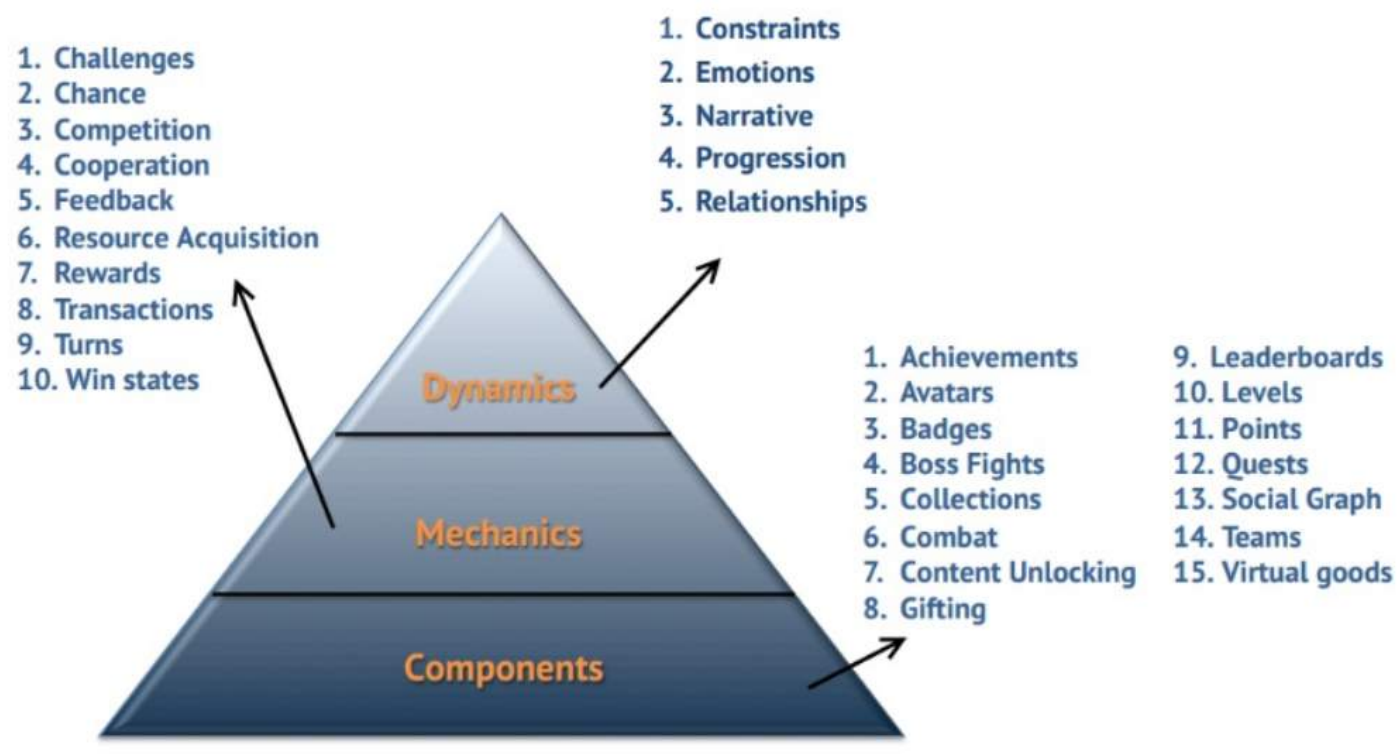

Figure 1: The Pyramid of Game Elements (Werbach ve Hunter, 2015)

Deterring et al. (2011: 12), states that the game factors are not peculiar to the game as they can be found in non-game environments. Game factors are characteristic of games, and for this reason games can only be appropriately defined with their own factors.

The keynote speaker of TNW Conference 2012 and the founder of a gamification website called www.gamification.co, Gabe Zichermann states that gamification does not mean to offer free things. Especially marketers and managers are trying to reward consumers and employees with something free. However, it is necessary to reward these people with status. People are emotional beings. Offering free products is a fast winning, but offering consumers status above their competitors has the potential to create longer-term brand loyalty (Zichermann, 2012).

Gamification strategy is based on motivation, game design and triggers. Everyone's motivation level may be different, as well as motivation tools. Unfortunately, it can be seen that, in most game models, internal rewards, where external rewards (money, fame, badges, compliment, etc.) are heavily used, are not adequate. It has been shown in many studies that external awards do not create permanent change (7summitsinc, 2013). Gamification is used to trigger emotions below motivation. When looking at the works of Harry Harlow (inner motivation) and Edward Deci and Richard Ryan (self-determination theory), it is seen that external motivation is a motivation form such as reward and feedback, which is not under our control and is formed by extrinsic direction. Intrinsic motivation is the motivation of an action we take with a decision coming from within us, which is the magic of gamification (cited in Yılmaz, 2018: 47-48). The main purpose of gamification is to provide the participants with the sense of game to exhibit the behaviors expected from them and to give internal and external rewards to motivate those who show these behaviors.

Marczewski (2019) reveals the factors of RAMP, relatedness, autonomy, mastery and purpose, which lead gamification based on the intrinsic motivation factors that Deci and Ryan position as autonomy, competency and relatedness. While relatedness means social and emotional bonding with other people, this desire is fulfilled by social status and networks in gamification. Autonomy is the need for freedom, self-expression, and creativity. Gamification allows users to make certain choices and express themselves. Mastery is the process of having skills in one field. In gamification, users are shown how close they are to the given target, what stage they are at and they are given various rewards at each stage. The goal is the desire to help others, is the want to know why what you do is 
important. In gamification, users are also trained in their roles, but in the meantime, a way that they can give back to others can be provided.

Werbach and Hunter (2015) provide a 6-steps frame for a successful gamification model. The steps of this model expressed as D6 are defining business goals, delineating target behaviors, describing players, devising activity loops, deploying tools, and adding fun.

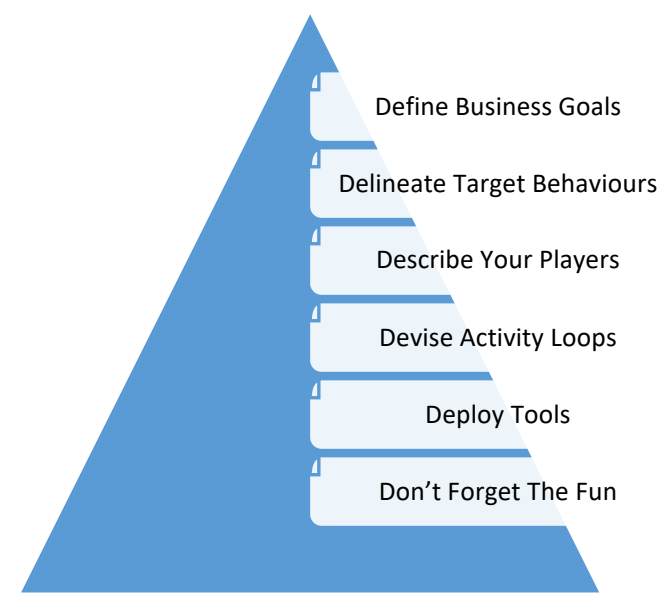

Figure 2: Werbach D6 Gamification Framework (Werbach ve Hunter, 2015)

The Octalysis gamification model developed by Yu-kai Chou identifies 8 Core Drives that motivate people to act (Yukaichou, 2014).

1. Meaning: This is the impulse that makes people motivated because they believe that they occupy with something bigger than themselves.

2. Accomplishment: Internal urge is needed in order to progress, develop skills and ultimately overcome the meaningful challenges.

3. Creativity: When a user enters into the process of creativity, he/she has to constantly try out different action combinations to solve the event and to continue.

4. Ownership: This is the drive that users are motivated because they feel they have something (fortune, properties, data, collections, etc.).

5. Social influence: All social factors that guide people; mentoring, acceptance, social reactions, friendship, competition, and envy.

6. Scarcity: This is the driving force of desiring something you can't have because it's a scarce source or you're denied access.

7. Unpredictability: The desire of those who want to know what is going to happen in the next step, such as watching a movie or gambling.

8. Avoidance: This core drive relies on avoiding anything negative. 


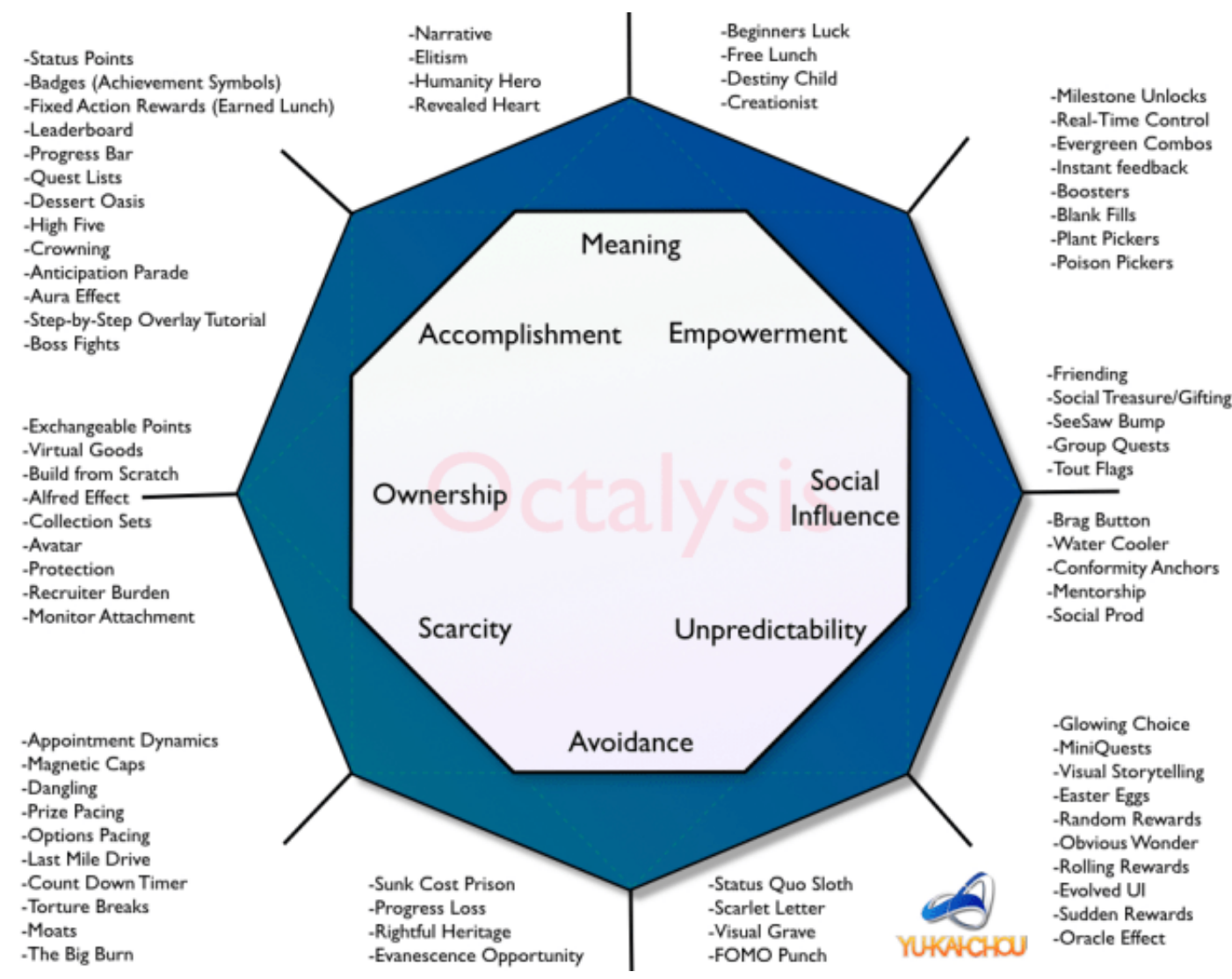

Figure 3: "Octalysis -The 8 Core Drives of Gamification (Yukaicho, 2014)

\section{Green Gamification as part of Public Interest Function of Public Relations}

Considering the social responsibility function of public relations, the concept of sustainability emerges. Lubin and Esty (2010) define the concept of sustainability as a developing megatrend that would touch every function, every line of business, every employee. Today, especially all organizations that aiming at sustainability are paying regard to social responsibility in their activities and in all relations with their target audiences. This responsibility could be expanded as in the form of all target audiences that organizations have the responsibility of which such as their employees, their consumers, nature and environment, government, society, etc.

In recent years, using game design factors in non-game content (gamification of content) has become an important trend in the industry. Game developer Jane McGonigal expresses in her book she wrote in 2011 called Reality Is Broken: Why Games Make Us Better and How They Can Change the World, that gamification has the power to save the world due to its potential to encouraging desired behaviors (Fors \& Lennerfors, 2016: 164). Software companies discovering this potential have launched many applications since 2010 to today that encourage energy-saving behavior, make recycling fun, and help the user to travel more environmentally friendly.

When we analyze the social responsibility applications in the international field, a new concept called green gamification appears. Green gamification has been started to use densely to increase and sustain user interest, and to promote specific behaviors, especially in environmental sustainability (Joy and Chiramel, 2017: 83). Gamification is a rapidly growing industry with the potential to help solve global climate and environmental challenges. With an application that is designed as using game design techniques and game mechanics in line with a certain ecological purpose, reaching the large masses and making the people act is possible. Based on the development of technology and the increasing usage of smartphones, organizations, non-governmental organizations and other social organizations use gamification techniques by creating various applications about this issue to raise awareness, and in some cases, to collect donations. 
There are many successful applications operating internationally in the fields such as energy saving, recycling, waste reduction and etc. International examples selected from these applications that motivate people to behave responsibly in protecting the environment, evaluate people's activities in this field, enable them to share and compete in social environments, promise them to have fun and save the planet with green gamification are explained in details below:

Opower: Opower is an American software company. The company, which signed an agreement with Facebook in 2012 in cooperation with the Natural Resources Defense Council on the issue of energy saving, has launched an application which internet users can compare their electricity expenditures with other users. Recording the electric expenditure information written by users on a daily basis, the application aims to raise awareness in limiting expenditures and energy consumption through the warning signals sending to users (Radikal, 2010). Besides, users can announce their progress in energy saving on their Facebook accounts and compare them with their friends. In addition, users have the opportunity to participate in competitions about decreasing energy use in households.

The company which aims to change people's attitudes and behaviors in energy saving, enables users to compare electricity consumption with similar houses in their neighborhood (such as the best neighbor, the average neighbor), with tools such as a mobile application and a manageable thermostat. The company also warns its users about saving, and with the words of Laskey, carries out "the world's largest behavioral science experiment" (Laskey, 2013). Aiming to change attitude and behavior, one of the main purposes of public relations, the company expressed that people who experienced Opower had decreased their energy consumption by $2 \%$ (1-terawatt energy saving per year) and saved 120 million dollars. Providing a powerful combination of behavioral science, data analytics and marketing techniques, the company had made energy saving fun by using the power of gamification and had used the basic factors of gamification such as rewards, badges and contests in its practices by using competition. More than 75 public institutions, which had seen how effective Opower is, had become partners with the company.

SAP: German software giant SAP uses gamification for reducing car emissions and the amount of money and fuel spent on company cars. The company developed an application called "TwoGo" that businesses can use to encourage their employees to make a saving. Created as a car information sharing system, TwoGo allows employees that use the application in Germany to connect and match their routes to each other (Weinreb, 2011). Thanks to this application, users can earn points, follow keep up with their friends and donate their money to charity organizations. There are also social factors in the application used by 20,000 registered employees. Users are matched in line with their common interests and have the opportunity to socialize, make friends and interact. Linking social aid to financial and environmental benefits through such applications not only enables users to save money and reduce fuel consumption but also ensures employees to participate in and persist their gaming efforts.

Joulebug: Joulebug, having the slogan "Play, Save and Share", is an application designed for iOS users to make their daily habits at home, work and game sustainable. The application gives users clues with the intent of reducing energy. Users compete with their friends for competitive energy saving, and the users who perform the most tasks receive various rewards. In the application that has sections such as simple actions, impact statistics, bonuses, "how-to-do" videos, helpful links, clues, leadership rankings, badges, latest sustainability news, local communities, users can share how they make a difference in energy usage and encourage their friends. In addition, the application promises to saving money, having fun and protecting the planet (joulebug, 2019). Supported by organizations such as Siemens, City of Austin, IKEA, Michael Baker International, Bose and Colorado State University, the application is available in free, paid standard and paid premium versions.

PracticallyGreen (WeSpire): The company, operating in the field of digital sustainability, helps global organizations and their employees adopt healthier and sustainable choices at work, at home and in social life. The company's cloud-based web and mobile applications provide the tools to raise awareness of sustainable applications, strengthen actions, and measure environmental, social and financial impact. For this purpose, the application uses social networks and gamification mechanics. The application was chosen as one of the great green ideas by Fortune Brainstorm GREEN in 2012. The company's cloud-based platform uses social networks and game mechanics to raise awareness of sustainable applications, strengthen actions, and measure impact. The company, 
having Unilever, CA Technologies, Sony Electronics, NBC Universal, Sony Pictures, and Caesars Entertainment among its clients, integrates with the organization's intranet, e-mail, and corporate index systems to enhance and monitor employee engagement initiatives. It can also be used on mobile devices. Features of the platform are Themed Projects (employees can work together on certain themed projects such as zero waste in the workspace), Repeatable Operations (certain repeatable actions on employee habits - such as using public transportation vehicles, turning off computer, using LED lamp), Advanced Social Features (in addition to commenting and liking, users can post photos and tag friends after completing an action).

RecycleBank: RecycleBank was established in New York in 2004 and aims to promote recycling, waste reduction and environmentally friendly habits. With its mobile applications, RecycleBank rewards people in order to make them show daily green actions by offering discounts from local and national businesses. With this application, when users recycle, they earn points and rewards from the contracted local and international companies (coupons, discounts, etc.). For instance, Footlocker and Dunkin Donuts are members of this program. With various reminders, user can follow daily recycling and garbage collection processes and share their savings (Recyclebank, 2019).

RecycleBank also works with municipalities and when it increases recycling, the company takes a fee from municipalities for saving. The company, rewarding households for the amount they recycle, helps them increase recycling by providing a recycling container to every house. In this system, the user is rewarded, municipality allocates less budget for garbage collection, investor and solution partners reach the users with various advertisements, so everyone wins. In addition to these, recycling companies have an increasing material acquisition thanks to RecycleBank, and some companies, such as Coca-Cola, recycle some materials like plastics, aluminum and cardboard and return them to the manufacturing supply chain (Zhao, 2008).

The application which allows the users to share their personal stories to encourage them and make them act also uses behavioral science to make people feel part of a team or society. Acting with the gamification strategy, the application uses the reward system for motivation. The user earns points for each friend he/she invites. RecycleBank has also established the One Twine site, which sells products in a variety of categories to attract consumers who want to buy environmentally responsible products. Users can earn discounts with their points here (Recyclebank, 2019). With this initiative, the company attracted the attention of the capital owners and investors, and the investors such as Kleiner, Perkins, Caulfield and Byers invested about 30 million dollars to the company. As a result, the recycling rate in societies using the RecycleBank program has doubled.

Oroeco (Gamified Climate App): Established in 2011 and has a slogan "A fun, easy and rewarding way for everyone to help solve climate change!", Oroeco is an application designed for carbon footprint tracking. It allows the user to monitor the impact he/she creates on the climate by automatically placing a carbon value on everything he/she buys, everything he/she eats, the energy he/she uses. Working together with University of California, Berkeley's CoolClimate research group and the US Environmental Protection Agency, the company compares the users' usage data as using scientific data.

The company, which has a mission to utilize technology to solve some of the world's biggest problems, states that people's daily choices (organic, fair trade, low-carbon, non-GDO, zero trans-fat, safe, biodegradable, non-toxic, cruelty-free, natural or local, etc.) are very important. With personalized tips, the company informs the user which saving will be beneficial for climate change. The application shows the users the effects on climate change at every stage of their lives from transportation to energy, diet, shopping and entertainment choices. With its carbon footprint calculator, it gives users the chance to challenge and compare their friends via Facebook on various subjects such as personalized tips on how to reduce the impact on the environment, savings tips on the spending issue, a reward-winning clean cook/kitchen project. The application that uses gamification technique has badges, rewards, status (such as climate champion status), scoreboard and level rankings (Oroeco, 2019).

Commute Greener: Designed by Volvo in 2009 to reduce the carbon footprint of its employees, this application was selected as an environmentally friendly project in 2011 by the technology magazine $\mathrm{ClO}$ that is published in Sweden. Using a personal carbon dioxide consumption 
calculator, the application has been able to reduce the environmental impact of its users by up to two times and has been brought into the use of society by being combined with a strong social user network. With this application, users can make choices to find the most environmentally friendly and efficient way to travel and can monitor the environmental impact of their choices. It was first used in Gothenburg, Sweden and later spread to the America continent. In addition to civilian users, city planners can use the data collected through this application to enhance traffic management, increase information on public transport usage, and public institutions can provide economic and social benefits.

Commute Greener is an application that can be used by an urban administration, by an organization or by individuals. Public institutions (municipalities, etc.) use Commute Greener to achieve measurable results of more sustainable daily trips (reducing carbon dioxide, improving health), to create new ways for urban travel (improve the citizens quality of life), to ensure action management and public participation. Organizations can use this application to increase employee engagement in order to achieve business goals, to obtain measurable results that contribute to sustainable development, to reduce carbon dioxide emissions, to decrease costs and to ensure social responsibility of the company. The application can be accessed via web, smartphone and Facebook. There are many sections in the application such as comparison and sharing of results with other users, reward (for instance a user who prefers public transportation can be rewarded with a free coffee by the application), challenge, badges, levels and socialization. It promises the individual user entertainment, miles and money saving, benefits for the environment, a better route to travel and a healthier life (Commutegreenerinfo, 2019).

\section{Green Gamification Model in Public Relations}

These mobile applications, which were taken as samples in order to form a model on green gamification and explained in details above, were examined in pursuant of Werbach and Hunter's D6 model and tabulated as follows.

\begin{tabular}{|c|c|c|c|c|c|c|}
\hline $\begin{array}{l}\text { Applicatio } \\
\text { ns and } \\
\text { common } \\
\text { specificati } \\
\text { ons }\end{array}$ & $\begin{array}{l}\text { Business } \\
\text { Goals }\end{array}$ & $\begin{array}{l}\text { Target } \\
\text { Behaviors }\end{array}$ & Players & Activity loops & $\begin{array}{l}\text { Gamification } \\
\text { Techniques }\end{array}$ & Used Tools \\
\hline $\begin{array}{l}\text { Opower } \\
\text { SAP } \\
\text { (Two Go) } \\
\text { Joule } \\
\text { Bug } \\
\text { Practically } \\
\text { Green } \\
\text { RecycleB } \\
\text { ank } \\
\text { Oroeco } \\
\text { Commute } \\
\text { Greener }\end{array}$ & $\begin{array}{l}\text { Energy saving } \\
\text { Fight with } \\
\text { climate } \\
\text { change/ } \\
\text { Recycling } \\
\text { Participation of } \\
\text { public } \\
\text { Collaboration } \\
\text { with public } \\
\text { institutions, } \\
\text { businesses } \\
\text { and NGO's } \\
\text { Employee } \\
\text { motivation } \\
\text { Communicatio } \\
n \text { with } \\
\text { stakeholders }\end{array}$ & $\begin{array}{l}\text { Raising } \\
\text { awareness } \\
\text { Raising } \\
\text { awareness of } \\
\text { energy saving } \\
\text { and sustainable } \\
\text { form of life } \\
\text { Changing } \\
\text { attitude and } \\
\text { behavior in } \\
\text { energy saving }\end{array}$ & $\begin{array}{l}\text { Individual } \\
\text { users } \\
\text { Employees } \\
\text { Businesses } \\
\text { Public } \\
\text { institutions } \\
\text { NGO's }\end{array}$ & $\begin{array}{l}\text { Activity } \\
\text { broadcast } \\
\text { Effect } \\
\text { statistics } \\
\text { Likes and } \\
\text { comments } \\
\text { Interactive } \\
\text { chat } \\
\text { Gradings } \\
\text { Share the } \\
\text { attachment } \\
\text { Society forums } \\
\text { Donating } \\
\text { Navigation } \\
\text { Calendar } \\
\text { Assistant links } \\
\text { Clues }\end{array}$ & 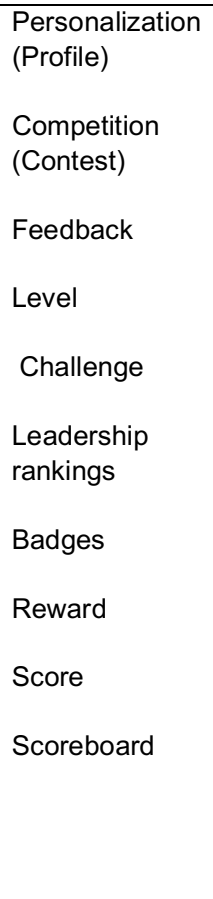 & $\begin{array}{l}\text { Website } \\
\text { Intranet } \\
\text { Corporate e-mail } \\
\text { Social media } \\
\text { (Facebook) } \\
\text { Mobile application }\end{array}$ \\
\hline
\end{tabular}

Table 1. Examination of green gamification applications in pursuant of Werbach and Hunter's D6 model 

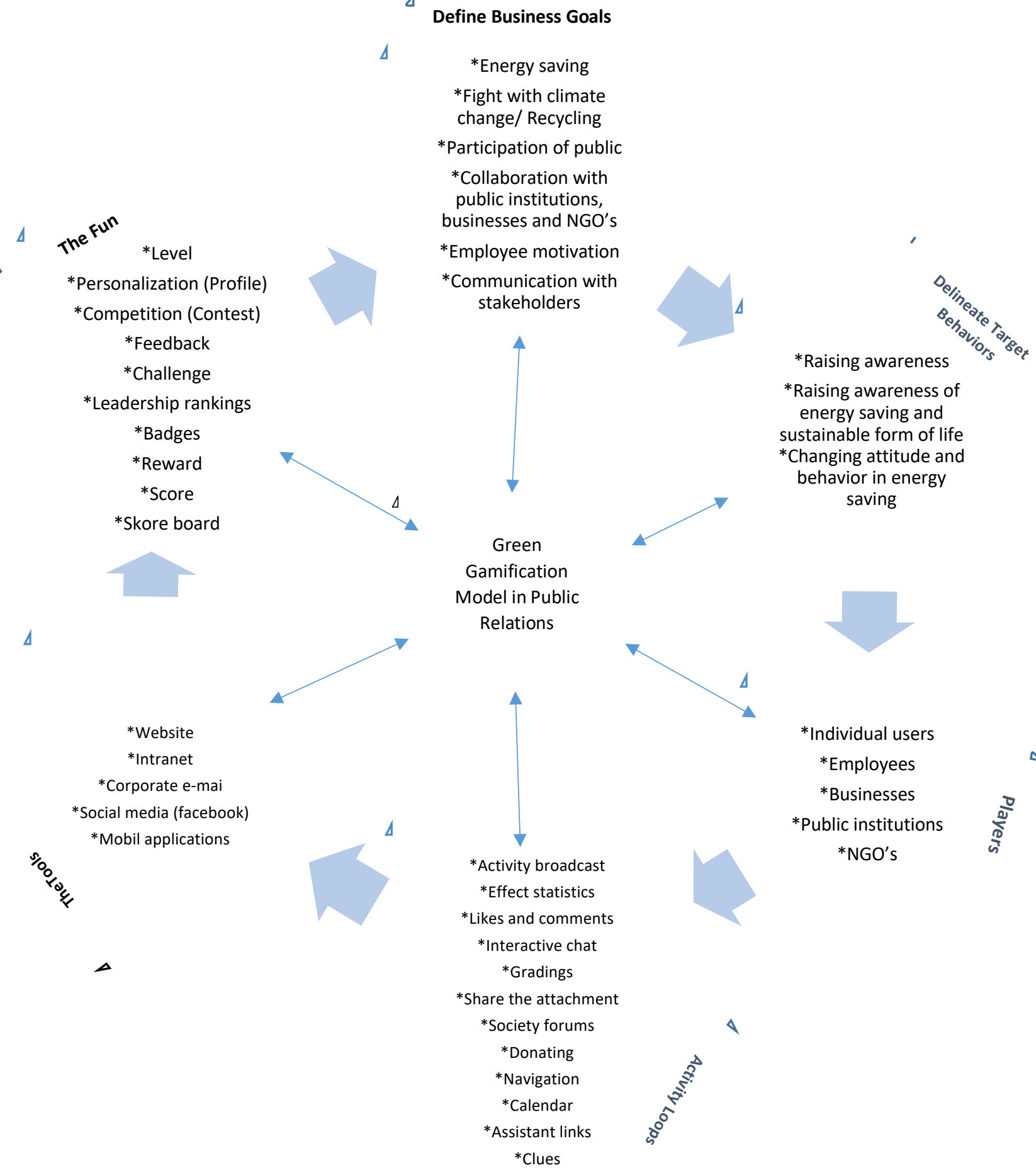

Figure 4: Green gamification model in public relations

As can be seen in Table 1 and Figure 4, the main goal of green gamification applications is to provide public participation as a business objective and to establish interactive communication with the target audience within the scope of public interest and social responsibility activities of the organization. In addition to the cooperation of public institutions and businesses, these applications, which can be opened to the usage of large target groups intended for NGOs and individual users, benefit from all public relations tools offered by digital media for interactive communication as activity loops. Using all the factors of gamification, many different incentives such as competition-based level, assignment, leadership rankings, badges, reward, score and contest are used in these applications. Alongside the mobile versions of all applications installed on smartphones, the collaborations with especially Facebook, which is one of the social media channels, attract attention. 

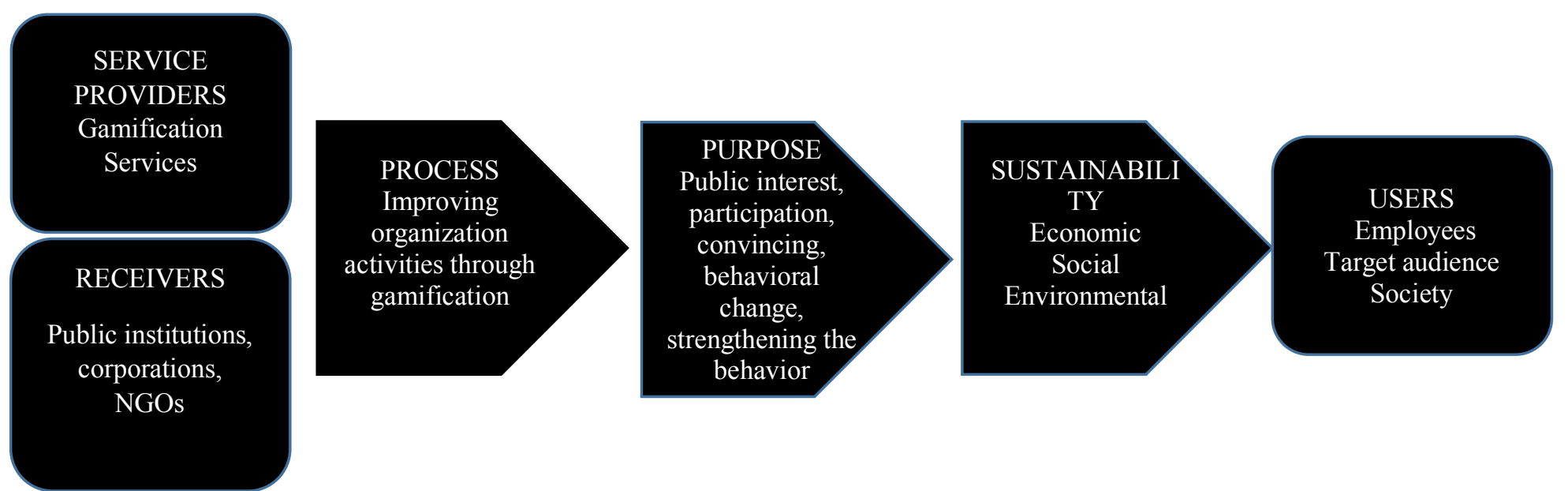

Figure 5: A Sustainable Gamification Process Model In Public Relations (Reinterpreted based on the mind map model of a sustainable gamification process model in tourism, in Negruşa et al., 2015: 11164)

In the light of all these data, the model in Figure 4 and Figure 5 comes in sight for a sustainable gamification process based on social responsibility within the frame of public interest function of public relations. The process that started with the cooperation of the companies that provide gamification service, and the organizations that benefit from them-as service provider and receiver- should base upon the main functions of public relations such as developing the aims and activities of the organization through gamification, to realize the public interest, public participation, persuasion, attitude and behavioral change and to realize the existing behavior within the scope of the organization's social responsibility. These goals should be formed and presented to the target audience in a way to provide economic, social and environmental saving/benefit to the organization in line with sustainability.

\section{Conclusion}

Today, it is known that the usage of digital media in the field of public relations provides organizations budget and time saving compared to traditional methods and offers an environment that they can communicate more effectively and ease of measurement. And therefore, gamification appears as a powerful tool in public relations practices aimed at creating attitude and behavioral change in the target audience. Gamification strategies enable game-based communication with the target audience. With an application that is designed using game mechanics and dynamics in line with a specific purpose, especially in sustainability, it is possible to make people act, to raise awareness and to create change in attitude and behavior. Gamification can also be used as an effective tool for socializing and public participation.

Public relations, which is an essential management mission for organizations, by its nature, must protect the public interest. One of the main goals of public relations is making the organizations and stakeholders adopt the social responsibility approach and integrating it into the corporate culture. Besides, the public relations executive who plans and implements the strategic communication processes should be aware of the social responsibility areas of the organization he/she represents and develop these works by considering all target audiences of the organization within the scope of sustainability. Especially in terms of sustainability, organizations need to be involved in activities in all areas that concern all the world such as energy saving, carbon footprint, and climate change.

When we look at the activities of international organizations, we can see that many organizations commissioned the service providers to create green gamification applications or supported these applications within the scope of their social responsibility purposes. The research did not find this type of application in our country. It is seen that there is no study in the literature about the concept of green gamification either. Although there are very few studies of the subject of the group, process, activity or situation that are wanted to be examined in the scientific literature, such studies are defined as exploratory studies. That's why this study is an exploratory study for guiding the interested researchers and proposes a sustainable gamification process model for public relations. 
According to this model, organizations can improve their works by integrating their activity loops (event broadcast, effect statistics, likes and comments, interactive chat, grading, sharing the attachment, participating societies, donating) and gamification techniques especially to mobile application, website, social media channels in line with their business goals and target behaviors. In our country, within the scope of sustainability works, public institutions, businesses, and NGOs can have green gamification designs suitable for their own purposes similar to the sample applications discussed in the research in order to both fulfill their social responsibilities and increase their social stakeholders and establish interactive communication. Or they can support these types of applications by making collaborations such as sponsorship. These kinds of applications will increase the organization's interaction and bond with the target audience, strengthen the public image and reputation, as well as enhance the support and loyalty to the organization.

\section{References}

[1] Akbulut, D. (2018). "Halkla İlişkilerde Oyunlaştırma Kavramının Kullanımı" Mersin Üniversitesi Uluslararası Dijital Çağda İletişim Sempozyumu Bildiri E-Kitabı, 96-107.

[2] Bilgin, L. (2010). Halkla Iliş̧kiler, İstanbul: Kum Saati.

[3] Bivins, T. H. (1993) "Public Relations, Professionalism and the Public Interest" Journal of Business Ethics 12: 117-126.

[4] Critical Elements of Gamification (2013) https://www.7summitsinc.com/wpcontent/uploads/2013/09/Critical-Elements-of-Gamification.pdf Accessed Date 14.04.2019

[5] Commute Greener resmi web sitesi, http://commutegreenerinfo.com/, Accessed Date 13.04.2019.

[6] Deterding, S.; Dixon, D.; Khaled, R.; Nacke, L. (2011). From Game Design Elements to Gamefulness: Defining "Gamification". In A. Lugmayr, H. Franssila, C. Safran, \& I. Hammouda (Eds.), Proceedings of the 15th International Academic MindTrek Conference: Envisioning Future Media Environments (pp. 9-15). New York, NY, USA: ACM. http://dl.acm.org/citation. $\mathrm{cfm}$ ?id=2181037.2181040 Accessed Date: 13.04.2019.

[7] Ehling, W. P. (2005). "Halkla İlişkiler ve İletişimin Örgüte Kattığı Değerin Tahmini" Halkla İlişkiler ve İletişim Yönetiminde Mükemmellik (Ed.James Grunig vd.) İstanbul: Rota Yayınları.

[8] Fors, P. \& Lennerfors, T.T. (2016). "Gamification for Sustainiability: Beyond the LudoAesthetical Approach", The Business of Gamification: A Critical Analysis, Ed. Mikolaj Dymek and Peter Zackariasson, New York: Routledge.

[9] Guevarra, L. (2011). "Volvo's App for Greener Commutes Wins Sustainability Award", https://www.greenbiz.com/news/2011/12/09/volvos-app-greener-commutes-winssustainability-award, Accessed Date 13.04.2019.

[10] Göksel, A.B. (2013) Halkla İlişkilerde Stratejik Operasyonlar, Ankara: Nobel Yayıncılık.

[11] How Green Gamification Can Save the Planet (and Utilies), (2019), https://www.getplayoff.com/blog/en/what-is-gamification-how-points-badges-challenges-andcharts-boost-the-companies-annual-turnover-1-0, Accessed Date 11.04.2019.

[12] Huizinga, J. (2018) Homo Ludens (Çev. Orhan Düz). İstanbul: Alfa

[13] Işık, C. (2003) "Kurumsal Sosyal Sorumluluk Nedir?" Marketing Türkiye Journal. Kasım.

[14] Johnston, J. (2016). The Public Interest: A New Way Of Thinking For Public Relations? Public Relations Inquiry, Vol. 6(1), 5-22.

[15] Joulebug Resmi Web sitesi, https://joulebug.com/, Accessed Date 11.04.2019.

[16] Joy, M.M. and Chiramel, M.J. (2017). Fun is the Future: A Collection of Compelling Gamification Success Stories, Educreation Publishing.

[17] Kaygısız, E. (2016). "Dijital Halkla İlişkiler Kavramı”. https://pazarlamailetisimi.com/dijitalhalkla-iliskiler-kavrami/ . Accessed Date 09.04.2019.

[18] Keynote Gabe Zichermann at TNW2012, (2012) https://www.youtube.com/watch?v=UdUclLUDxRg Accessed Date 10.04.2019

[19] Kriz döneminde bir çıkış yolu olarak: Oyunlaştırma ve içsel motivasyon (2018). DigitalAge. https://digitalage.com.tr/kriz-doneminde-bir-cikis-yolu-olarak-oyunlastirma-ve-icsel-motivasyon/ Accessed Date: 13.04.2019.

[20] Laskey, A. (2013). Ted Talks: How Behavioral Science Can Lower Your Energy Bill, https://www.english-video.net/v/tr/1754, Accessed Date 10.04.2019.

[21] L'Etang J. ve Pieczka, M. (2002) Halkla İlişkilere Eleştirel Yaklaşımlar. Ankara: Vadi Yayınları. [22] Lubin, D. A \& Esty D.C. (2010). "The Sustainability Imperative", Harward Business Review, https://hbr.org/2010/05/the-sustainability-imperative Accessed Date 10.04.2019. 
[23] Maden, D. (2012) "Durum ve Örgüt Analizi”, Stratejik Halkla İlişkiler Yönetimi (Ed. Göztaş, A. ve Topsümer, F.). Ankara: Seçkin Yayıncılık.

[24] Marczewski, A. (2019). "Introduction to Gamification Part 4: Motivation (R.A.M.P, Maslow, SDT and more)" https://www.gamified.uk/2019/01/30/introduction-to-gamification-part-4motivation-r-a-m-p-maslow-sdt-and-more/ Accessed Date 09.04.2019.

[25] McGonical, J. (2011) Reality is Broken: Why Game Make Us Better And How They Can Change The World. NewYork: Penguin Books.

[26] Mechling, T. B. (1975) "Is Public Interest Public Relations Practical and Desirable?" Public Relations Quarterly, Summer, 10-22.

[27] Messina, A. (2007) "Public Relations, The Public Interest And Persuasion: An Ethical Approach", Journal Of Communication Management, 11, (1), 29-52,

[28] Negruşa, A.L. (2015). "Exploring Gamification Techniques and Applications for Sustainable Tourism", Sustainability 2015, 7, 11160-11189; doi:10.3390/su70811160, www.mdpi.com/2071-1050/7/8/11160/pdf, Accessed Date 13.04.2019.

[29] Octalysis - The World's \#1 Gamification Framework (2014) https://yukaichou.com/gamificationexamples/octalysis-complete-gamification-framework/ Accessed Date 14.04.2019

[30] Octalysis - the complete Gamification framework (2014) https://yukaichou.com/gamificationexamples/octalysis-complete-gamification-framework/ Accessed Date 14.04.2019

[31] One Twine Resmi Web Sitesi, https://onetwine.recyclebank.com/, Accessed Date 12.04.2019

[32] Oroeco Resmi Web Sitesi, https://www.oroeco.com/about, Accessed Date 13.04.2019.

[33] Peltekoğlu, F.B. (2007). Halkla İlişkiler Nedir? İstanbul: Beta Yayınları.

[34] Practically Green Introduces New Enterprise Platform for Engaging Employees in sustainability and Corporate Responsibility, (2013), https://www.wespire.com/press$\mathrm{room} /$ practically-green-introduces-new-enterprise-platform-for-engaging-employees-insustainability-and-corporate-responsibility/, Accessed Date 11.04.2019.

[35] Public Relations Defined: A Modern Definition For The New Era Of Public Relations (2012). http://prdefinition.prsa.org/ Accessed Date 03.04.2018.

[36] Public Relations Definition (2008) https://www.cprs.ca/About.aspx, Accessed Date 03.04.2018.

[37] Radikal (2010). Facebook'la Enerji Tasarrufu, http://www.radikal.com.tr/cevre/facebooklaenerji-tasarrufu-1066795/ Accessed Date 10.04.2019.

[38] Reyclebank Resmi Web Sitesi, https://www.recyclebank.com/, Accessed Date 12.04.2019.

[39] Recyclebank at 10: What we've learned, (2014), https://www.greenbiz.com/blog/2014/10/02/recyclebank-10-what-weve-learned, Accessed Date 12.04.2019.

[40] Sözer, E. (2018). "Halkla İlişkilerin Dönüşümü: Dijital PR" https://www.brandingturkiye.com/halkla-iliskilerin-donusumu-dijital-prl, Accessed Date 09.04.2019.

[41] Tezsezen, H. A. (2017). "Dijital halkla ilişkiler nedir? Araçları nelerdir?" https://indigodergisi.com/2017/08/dijital-halkla-iliskiler-nedir/ Accessed Date 11.04.2019.

[42] What is Gamification? How Does Gamification Work? https://www.bunchball.com/gamification Accessed Date 10.04.2019

[43] Weinreb, E. (2011). "How to Score Epic Green Wins in the Workplace with Gamification", https://www.greenbiz.com/blog/2011/12/12/how-score-epic-green-wins-workplace-gamification, Accessed Date 11.04.2019.

[44] Werbach, K. and Hunter, D. (2015). The Gamification Toolkit: Dynamics, Mechanics, and Components for the Win. Philadelphia: Wharton Digital Press.

[45] Werbach, K. and Hunter, D. ( 2012). For the Win: How Game Thinking Can Revolutionize Your Business. Philadelphia: Wharton Digital Press.

[46] Yıldırım, G. ve Karafes, E. (2011). "Halkla Illişkilerin Dönüşümü: Public Relations'dan Public Engagement'a Geçiş”. Anadolu Bil Meslek Yüksek Okulu Dergisi, 6(24), 17-26.

[47] Yılmaz, E. A. (2018). Yeni Nesil Motivasyon:İşte Oyunlaştırma. İstanbul: Ceres Yayınları

[48] Zhao, L. (2008). "Rewarded for Recycling”, RecycleBank CEO'su ve Kurucusu Ron Gonen Röportajı, Forbes Dergisi, Aralık, https://www.forbes.com/2008/12/22/recyclebank-rewardsredeem_leadership_clayton_in_lz_1223claytonchristensen_inl.html\#bc98e9a46cbb, Accessed Date 12.04.2019.

[49] Zichermann, G. \& Cunningham, C. (2011). Gamification By Design: Implementing Game Mechanics İn Web And Mobile Apps, CA:O'Reilly Media, Inc. 